TITLE:

Association Between the Discrepancy in Self-Reported and Performance-Based Physical Functioning Levels and Risk of Future Falls Among Community-Dwelling Older Adults: The Locomotive Syndrome and Health Outcomes in Aizu Cohort Study (LOHAS)( Abst ...

\title{
AUTHOR(S):
}

\section{Kamitani, Tsukasa}

\section{CITATION:}

Kamitani, Tsukasa. Association Between the Discrepancy in Self-Reported and Performance-Based Physical

Functioning Levels and Risk of Future Falls Among Community-Dwelling Older Adults: The Locomotive Syndrome and Health Outcomes in Aizu Cohort..

ISSUE DATE:

2019-11-25

URL:

https://doi.org/10.14989/doctor.r13293

\section{RIGHT:}

DOI: 10.1016/j.jamda.2018.09.009 


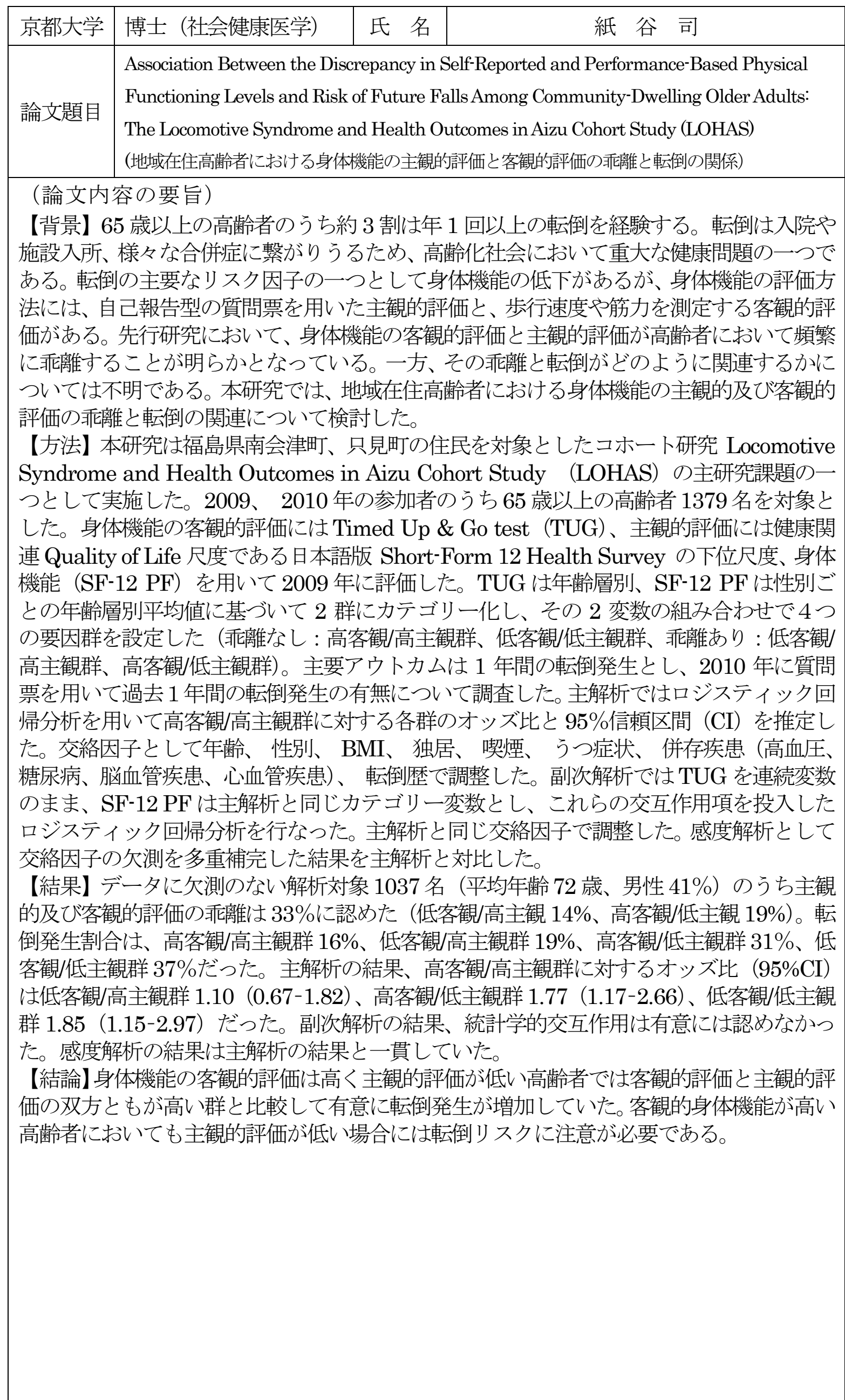

（論文審査の結果の要旨）

背景】地域在住高齢者における身体機能の主観的及び客観的評価の乘離と転倒の関連につ いて検討した。方法】地域住民を対象としたコホート研究 LOHAS の 2009、2010 年の 参加者のうち 65 歳以上の者を対象とした。身体機能の客観的評価にはTimed Up \& Go test、主観的評価には日本語版 SF-12 の下位尺度（身体機能）を用い、それぞれを性別・ 年齢層別平均值に基づいて二值化し、4つの要因群（高客観/高主観、低客観/高主観、高 客観低主観、低客観低主観）を設定した。主要アウトカムは 1 年間の転倒発生とした。 ロジスティック回帰分析を用いて高客観/高主観群を参照群としたオッズ比と $95 \%$ 信頼区 間 (CI)を推定した。交絡因子として年齢、性別、BMI、独居、喫煙、抑うつ症状、併 存疾患 (高血圧、糖尿病、脳血管疾患、心血管疾患)、転倒歴で調整した。【結果】解析対 象者 1037 名のうち主観的評価と客観的評価の乘離を 33\%に認めた。高客観高主観群に 対するオッズ比 $(95 \% \mathrm{CI})$ は低客観/高主観群 1.10 (0.67-1.82)、高客観/低主観群 1.77 (1.17 -2.66)、低客観低主観群 1.85 (1.15-2.97)だった。結論】身体機能の客観的評価は高いが 主観的評価の低い群では、双方の評価が高い群と比較して有意に転倒が増加した。客観的 身体機能が高い高齢者においても主観的評価が低い場合には注意が必要である。

以上の研究は高齢者における身体機能の主観的及び客観的評価の乘離と転倒の関係を 明らかにし、高齢者における新たな転倒予防方略の確立に寄与寸るところが多い。

したがって、本論文は博士 (社会健康矢学) の学位論文として価值あるものと認める。

なお、本学位授与申請者は、令和元年 10 月 31 日実施の論文内容とそれに関連し た研究分野並びに学識確認のための試問を受け、合格と認められたものである。 